\title{
THE ACTIVE MODEL OF A SOCIAL PROGRAMME AND ITS STRATEGIC ADVANTAGE
}

\author{
Venelin Terziev \\ Corresponding Member of the Russian Academy of Natural History, Moscow, Russia, Prof. D.Sc. \\ (Ec.), D.Sc. (National Security), D.Sc. (Social Activities), Ph.D., National Military University, Veliko \\ Tarnovo, Bulgaria; University of Rousse, Rousse, Bulgaria, terziev@skmat.com
}

\begin{abstract}
This article examines the classical complex social programmes, the methodology for their development and their key features. An analysis of the social regulation system is also included. Furthermore, it examines in detail the mechanism of developing an active targeted social programme, as well as the components of the mechanism for launching the latter. In addition, a description of a system of criteria for the efficiency of the social activity is provided.
\end{abstract}

Keywords: social programme, efficiency criteria, social regulation.

\section{INTRODUCTION}

Classical complex targeted social programmesare traditionally used in the command-administrative (totalitarian) social system. Within that system the programmes were developed and implemented predominantly separately from each other and were bound up with the state centralised planning- namely directive, perspective and ongoing planning. These social programmes are implemented in accordance with the external social environment. They depend on state funding and budget planning. At the same time, they do not allow significant adjustments to be made by the subject and the object of management on the adjustments of the inter-programming social plan, the interaction between the participants in the social programmes and the adjustments of the relatively social assessment of the programme implementation.

The said principles of social programming are insufficiently effective in the context of democratic transformations. In situation of social instability the classical form of the social programmes needs significant adjustment. The practice of social programming should abandon the obsolete programmes, lacking flexibility, that have not been updated for a long period of time. Despite the progress in the field of labour and social development today, still, social policy is grounded to an insignificant extent on science, on the strategy for finding human development resources, on a well-planned staff policy, on scientific and methodological principles of development of the social sphere and on scientific and practical studies of current social problems. Those factors that are inapplicable to the health of the population e.g. sustainable ecosystem development, including the quality of social education, the level of organizational culture of the institutions, the structure of the establishments in terms of professional skills and qualifications, the qualification level of 
the specialists working with the population, are often disregarded. The ideology of social service as a whole is gradually loosening its bonds with the old system of social protection; however, the final separation from the paternalistic position has not been achieved so far.

The democratic changes require new ideology of development and implementation of social programmes. The general public is no longer able to choose social goals as a component of targeted actions that remain unchanged over time, since the change in the conditions of the social living activity increases the necessary adjustments to be made in the implementation of the social programme. The social programmes should allow for active partnership interaction between their participants and should introduce the principle of democratic interaction with the object of social influence. The link between the contemporary social programmes and the state financial and budget planning should not be severed. The main source of resources for the said programmes should be formed on the basis of the budgets on a national and regional level.

The classical complex social programmes are focused on defining their social efficiency through the efficiency of capital investments, whilst disregarding to a certain extent other investments (including social investments, investments in educational, scientific and human capital). It is considered that under the conditions of a stable social environment it is not necessary to record the partial changes of the social programme in the accounting indicators of the latter. Consequently, the indicators of social and economic justifications, achieved with the help of the applied regulatory requirements, would be positive as a rule, while the actual social results from the human resource development would often be negative and, paradoxically, would not affect in any way the subsequent stages of the social programme implementation.

At the end of the 1980s of the last century the scientific publications put the use of the classical approach to the development of social programmes under severe criticism. It was pointed out that the social programmes underpinning the implementation of the social policy should cover the whole range of human needs and interests. The object of the social programme should be determined by the flexible impact on „the status of the classes and social groups, nations and nationalities, the social, class and national relations, the status of the individual in the society and his/her relation to it, all aspects of the national welfare pertinent to the society and its classes, social groups and ways of life". Scholars argue that it is necessary to significantly expand the area of influence of the social programmes, it is crucial to use them together with proved social technologies and new, more flexible and socially mobile, i.e. effective means of influence over social processes. "The abandonment of recognized management methods inevitably disturbed the stagnant balance of the social processes; it will reveal many latent conflicts and problems and will give surge to new ones. At the same time, the reform of the political system opens up opportunities for solving these problems by means of scientific research and democratic benchmarking of the various ᄀalternatives before the social policy". The new conditions turn out to require an adjustment of the main approach to the development of social programmes. At a time of a reform the given basic principles require the presence of a flexible mechanism for the free formation and manifestation of the interests and wills of all classes and social groups, their flexible coordination and realisation in the process of development and implementation of social programmes.

During the 1990s the social programmes were characterised not only by their rigidity and social inefficiency, but they also reflected the negative context of the corruption, which had turned into a resilient system of relations. Specific relationships were formed between entrepreneurs and officials, not as a cooperation in achieving the social goals, but rather as a means of taking away a financial resource to the benefit of a restricted group of people. The serious disruptions in the implementation of the social programmes lead to loss of their social efficiency and subsequent crisis phenomena, reflecting the ineffeciency of the social policy on a macroeconomic level, because the losses for the general public outweigh many times the social benefits it would have gained if the social programmes had been implemented.

According to people canvassed the main objective of the social programmes in Bulgaria in the last years was to ensure stability rather than development of human resources and support for disadvantaged people.

New theoretical approaches and a new model of active, dynamically self-improving social programmes capable of adapting to the changeable social life conditions have sprung up during the building of the information society. While there is a growing real need under the new conditions to orient the social programmes to solving the problems related to the intellectual educational development, the characteristics of health and physical development do not lose their social significance. Today the health of the population is a true indicator of the welfare of the country, the quality of life and the level of development of human resources. Health is directly related to per capita income and healthcare maintenance.

In summary, we can say that the contemporary social programmes unde market economy coditions can gain 
various forms which have their specific principles, methods, technologies for defining and achieving the social goals, paths and means of developing human resources. The general tendency in planning and implementing social programmes for human resource development is that their primary goals are oriented to solving the problems related to the health and physical development of the population and the intellectual educational development of the human resources.

The application of the social programmes under the conditions of the contemporary market production system requires not only comprehensive knowledge and understanding of its nature, but also creative skills to use the various forms of a social management method, establishing detailed technological procedures for designing and implementing social programmes in compliance with the principles of systematic social management.

Objectively speaking the population prefers to participate in active social programmes, consisting of active projects as a set of chain projects based on social processes directed to human development. The social processes based on active programming and project development, have an unbalanced, dynamic character and therefore they are in the foreground within the active social programmes. The foundation of the social resources used to support the programmes can be structured, so to say, of a combination of at least three support layers, which taken together, form the space of the flows of social support resources. The first layer, i.e. the first resource foundation of the space of flows, consists of a chain of electronic systems (telecommunication, computer processing, broadcasting and high-speed transport based on information technologies). The second layer of the space of flows consists of nodes and communication centres. These are mainly big social institutions which are the connection point with the world network for the support of social projects. „The third important layer of the space of flows concerns the spacial organisation of the dominant management elite which performs managerial functions and forms the center around which organisational space is built. The technocratic, financial and management elites which have a leading role in our society, have their specific spacial requirements related to the material and spacial foundation of their interests and actions".

Under the new conditions the development of programmes requires the inclusion into the implementation mechanism of active research and innovation work aiming their self-improvement. The adequacy of the programme and targeted social management under the conditions of an unstable and constantly changing way of life is determined by its focus on the active analysis of the results from the implementation of the social programme (social assessment of the results from the implementation) and on the attraction of broad groups of people for its development. The active social programmes form a system of social projects with direct social interaction and a feedback from it which defines the possibilities for adapting the components of the programme to its changing requirements. Morover, with regard to the implementation of the social programme, its social goals, deadlines and partly its participants can be changed and the involved social resource can be transformed.

Under the present day conditions the active social programmes essentially reflect the transition from the traditional to the innovative model of social development. This transition determines the complex use of the social programmes within the framework of innovative creativity, the partnership relations between the participants in the programme, the delegation of auxiliary functions to subordinate structures, as well as the broad participation of the population in the implementation of the programmes (Fig. 1).

\section{MATERIAL AND METHODS}

The methodology for developing an active social programme places an emphasis on the following theoretical components:

Identifying the social problem. „Getting a better understanding of the problem and gaining a more resonable control over certain key processes, we can turn the crisis into an opportunity, helping people not only to survive, but also to make the best of the change and to achieve a new experience of dominance over their own destiny";

Defining the social goal of the programme is the starting point of programming the process of human resource development. The external social environment gives an objective characteristic of the surrounding conditions, parameters and structure of the external objects, which interact more or less with the given object;

The planned trajectory of human resource development is projected within and by taking into account the set of national and regional programmes to be implemented, in accordance with the predetermined social criteria; 


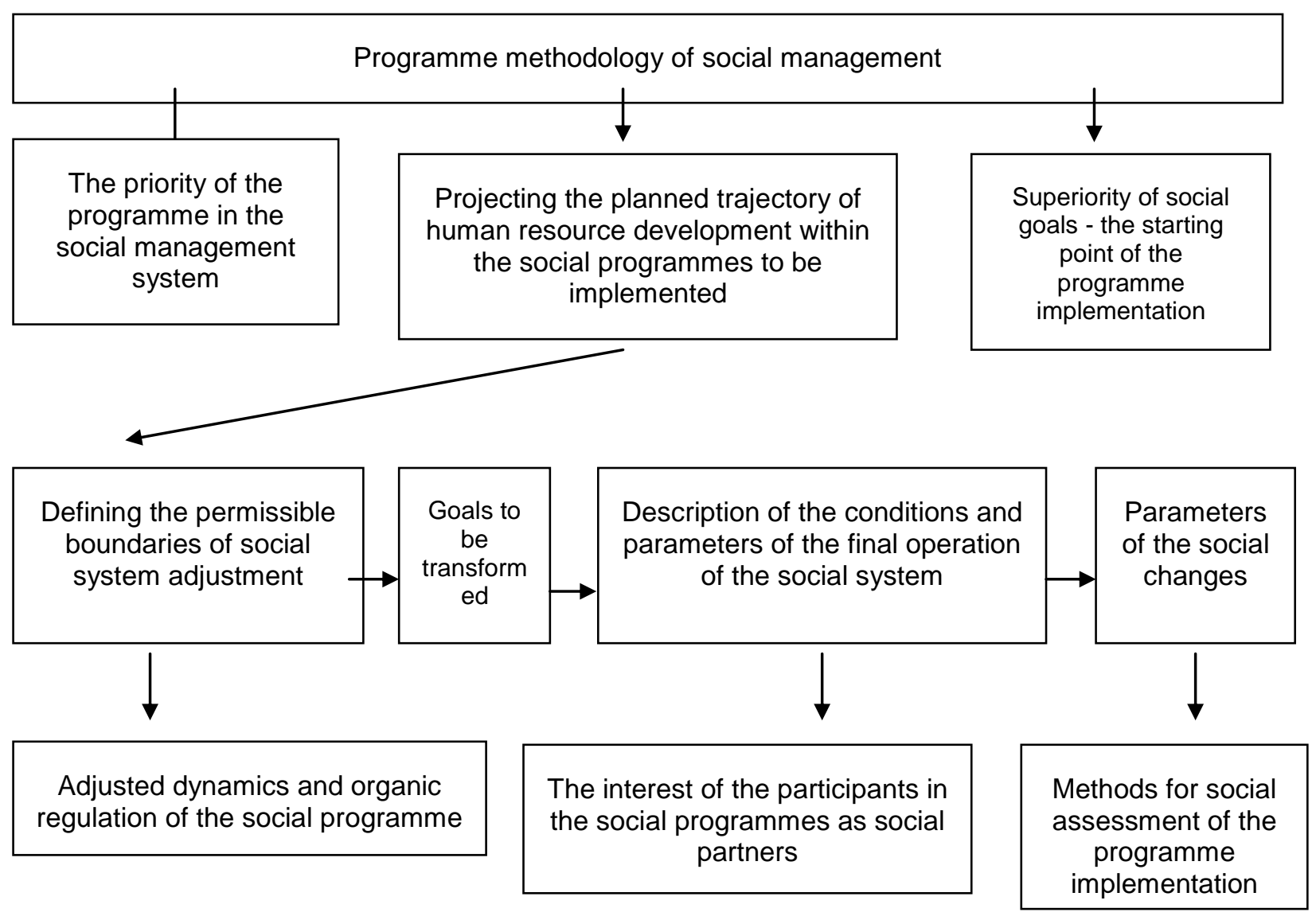

Fig. 1: Essential features of the active social programme

In order to plan the trajectory of human resource development, the following objective tasks need to be performed: First, defining the initial coordinates of the process of human resource development. Second, describing the conditions and parameters of the final state / final coordinates of the trajectory. Third, establishing criteria for qualitative and quantitative indicators of human resource development.

Many works by mathematicians have been published, related to planning and building a projected trajectory of the managed system. While examining in detail a few tests that use the results from such studies, we reached the conclusion that the mathematical approach to a problem has a limited practical significance when devising methods for influencing human resource development. The trust-worthiness of the above statement is corroborated by the fact that „each attempt to transfer the object... through management actions... from the initial state to the desired final state reveals the impossibility in principle of mathematically defining the initial conditions of the object precisely". The need for formalisation of theimpact of the external disturbance of the system on the living activity of the population faces a similar problem.

Therefore, it is relevant to maintain the conditions for material consumption and the level of the health of the population, as well as to plan the trajectory of the educational development of human resources. In the future the current system of scientific and educational institutes will become a base element of the information society as a society based on information resources, as well as on self-training educational systems. In the contemporary models of active social programmes it is necessary to provide for a trajectory of an anticipatory education of the population. The educational development should be continuous and should anticipate the targeted training, self-training, repeated training of the population and other forms of training. The anticipatory education in its abstract form looks like an ideal which the educational process could strive to achieve by shifting its development focus from the past to the present and the future. „The uncertainty of the future could be significantly reduced by setting apart the most desirable and at the same time the most realistic tendencies among the various alternatives and forecasts that stretch to the future, which is susceptible to guidance (manageable impact). Such tendencies and features of the future can turn into a normative vision of the societal development or certain spheres of its activity" 
We should mention that the most important goal of the contemporary social programmes is defined by the anticipatory level of knowledge, foreseeing and achieving socially significant consequences of the future when forming the general educational process. Reaching a certain goal can serve as a criterion during the implementation of the model of anticipatory education as a basis for the social construction of anticipatory human development. The social construction is essentially an aggregate result from the implementation of a set of active social programmes of the society. The anticipatory educational development of human resources on societal level reflects the transition of the individuals from one „social and professional stratum to another, accompanied by the development of skills and needs of the individuals through the acquisition of some or other set of cultural universalia - language, symbols, customs, traditions, societal norms, general and specific knowledge, translating into the education and self-training system of the society and presenting an opportunity for continuous objectivisation of personal skills, habits, experience in the system of the social professional activity".

The pivot in the search for optimal forms of social construction is the dynamically developing educational system and the corresponding new type of developing intellect and new kind of personality. This position can be justified with the fact that the educational system represents a social industry which trains specialists with one way of thinking or another; it is a spiritual targeted development of various types of individuals, i.e. in essence, this is a system of expanded reproduction of the spiritual culture of the members of certain society. The society transforms and develops quickly, whereas the system of educational institutions and the pedagogical practice are „a narrow space” for this process. Educational institutions of various ranking report an increase in the numbers of graduating specialists, without showing any concern about the adequacy of their qualities with regard to the increasing needs of the contemporary social development. This discrepancy can be overcome by creating conditions for competition among the structural elements of the educational system targeted at developing the literacy of the various strata of the population". Ihe educational developments of human resources, in determining the set of acquired systematic knowledge, skills and professional habits, as well as the developed abilities for further learning and analysis of the knowledge, the exchange and use of information in the professional activity, are notably the factor and the social goal of the overall social policy, which are most important.

The active social programme is characterised by a dynamic adjustable regulation through the feedback from its implementation. The functions of the adjustable regulator are some kind of a solution to the optimisation of the programme components as a result of the changed conditions of the living activity of the population suppressing the disturbing external social impulses that occur during the implementation of the social programme.

The adjustable regulator of the programme consists of three interrelated parts: the systems for social research, the organic system for planning and the organic system for regulation. The system for social research is put into practice with the help of methods studying the social interests of the population. The social research reveals the needs and preferences of the population to certain goods: a dwelling, health improvement, sports and cultural needs, qualification improvement and retraining of the personnel. The social planning is carried out with a view to solving a social problem that has occurred as a result of the nonconformity of the components of the social programme with the modified requirements. The social regulation is a process of creating conditions for active implementation of the social programme. The successful implementation of the social regulation helps unite the participants in the programme and bring closer their interests and the interests of the population which is the target of the programme.

The components are structurally identical and consists of the following interrelated parts: forecasting/anticipatory presentation of the reality/; planning the social changes in the system components; an imitation model of developing the programme implementation; internal direct adaptor of the programme management system, an external adaptor of the programme management system; an internal adaptor of the programme management system.

The principle of anticipatory reflection of reality provides for the adaptation of society to the changing conditions of the environment and the very possibility for existence - the capacity for awareness of the present and future reality. The anticipatory reflection of the social reality is one of the forms of presenting the future social development, which is "a historical foundation for the occurrence of all supreme forms of foreseeing future events and most of all for the occurrence of the conditioned reflex".

The principle of anticipatory reflection of reality within the social programme takes into account the determination of the future characteristics of the designed impact: social anticipation, social forecast, social design, social programming, social planning, social construction, social engineering. By using the principle of anticipatory reflection of the social reality "the principle of anticipatory reflection of the social reality can be sociologically established as a fundamental principle of social design". 
Under the new conditions the theoretical paradigm of the social programmes need synthesis with the theory of active systems, which would create conditions and montivational activity among the participants in the targeted social programme. This activity of the system element corresponds most closely to the model of targeted active social programme whose implementation requires individual participants to be enlisted: the population, government and public social institutions (Fig. 2).

The theory of active systems transforms into a section of the theory of programme social management, determining the social adaptability of the social programmes, the use of more participants in the programme and their activity. This activity of the system element corresponds most closely to the active model of the social programme. The activity consists in partner independence and interest of the participants in the programme. The coordination of the efforts aimed at achieving the social goals of the programme should be combined with the deriving of social benefits by its participants.

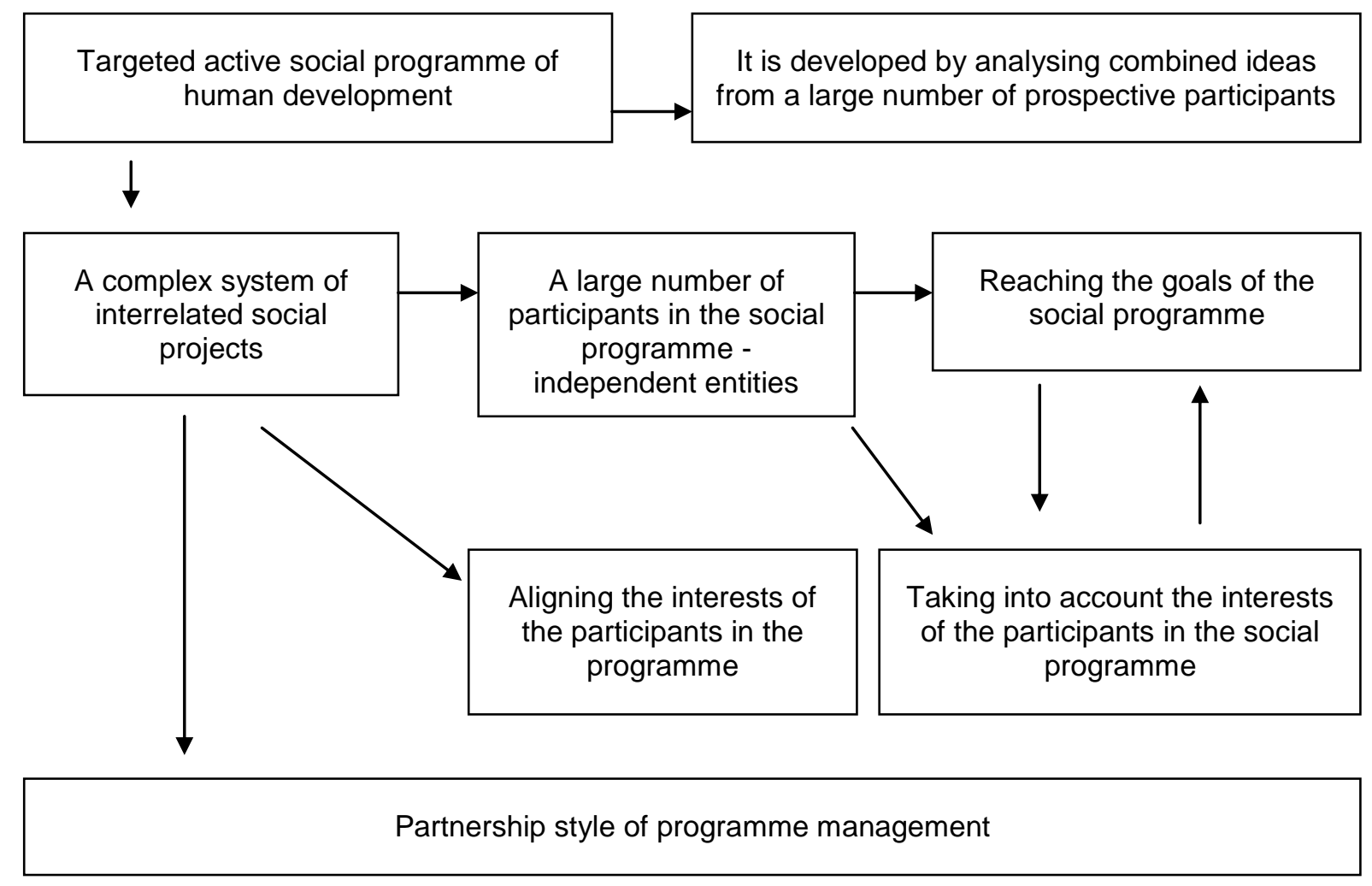

Fig. 2 Features of the targeted active social programme of human development

The social programmes assume an active character as a result of expanding the composition of the participants in the programme and uniting them systematically by applying the principle of partnership, as well as a result of the economic stimulation and activation of their social actions, i.e. the possibilities for making a strategic choice by the participants in the program are intentionally created within the implemented social programme. This implies that when developing the social programmes the participants undertake a social task relevant to them at the expense of their participation. The active model of the social programme provides for the creation of conditions where participants would benefit from their participation in the social programme. In the active targeted programme systems the controllable subjects are placed under certain conditions and have active increased managerial powers. Of significance here are the conditions and possibilities for a free choice of one's own state, the possibility to show one's own interests and preferences, i.e. they intentionally choose their state, but only within the priority of the implemented social programme. The active model of the social programme reflects the network structure of the social management when implementing the programme, where each participant in the targeted social programme has a high level of freedom of action and they strive to select optimal stategies in terms of the targeted results 7 under the defined or foreseen significance of the used social potential.

\section{RESULTS}

The activation mechanism of the development of an active targeted social programme has four components (Fig. 3) (Terziev, 2017, 318 str.; Terziev, 2018, 307 p.; Terziev, 2015, 110 p.; Terziev, Arabska, 2015a, 198 p.; Terziev, Georgiev, 2018a, str. 970-975; Terziev, Georgiev, 2018b, str. 959-969; Terziev, Georgiev, 
2018c, str. 188-193; Terziev, Georgiev, 2018d, str. 177-187; Terziev, Banabakova, Georgiev, 2018e, pp. 935-944; Terziev, Banabakova, Georgiev, 2018f, pp. 973-980; Terziev, Banabakova, Georgiev, 2018g, pp. 1275-1281; Terziev, Banabakova, Georgiev, 2018h, s.93-98; Terziev, Banabakova, Georgiev, 2018i, s. 99104; Terziev, Banabakova, Georgiev, 2018j, s. 104-109; Terziev, Banabakova, Georgiev, 2018k, s. 110-115; Terziev, Banabakova, Georgiev, 2018I, s. 116-121; Terziev, Banabakova, Georgiev, 2018m, s. 122-127; Terziev, Banabakova, Georgiev, 2018n, s. 127-131; Terziev, Banabakova, Georgiev, 2018o, s. 132-137; Terziev, Banabakova, Georgiev, 2018p, s. 137-142; Terziev, 2017a, pp.505-516).

The first component - the participants in the programme have geat freedom when selecting actions in accordance with the goals to fulfil their interests. In other words, each paticipant in the social programme has an interest in tackling a task relevant to him/her at the expense of his/her participation in it.

The second component - the existence of a body with a wide range of managers of the social programme and wide public participation. This body should not only examine the social results from the implementation, collect data, assess the implementation stages of the programme as a whole, but also develop guidelines for the corretion $\urcorner$ of the programme elements.

The third component is determined by the system for motivating a wide range of participants in the programme. The development and the implementation of the social programme require a specific form of stimulation the active free thinking, enterprising, scientific style of work which contributes to self-training, creativity and innovative development at the workplace.

The fourth component - the need for a permanent innovative centre which will support the innovative improvement of the social program and the activation of the processes for its renovation.

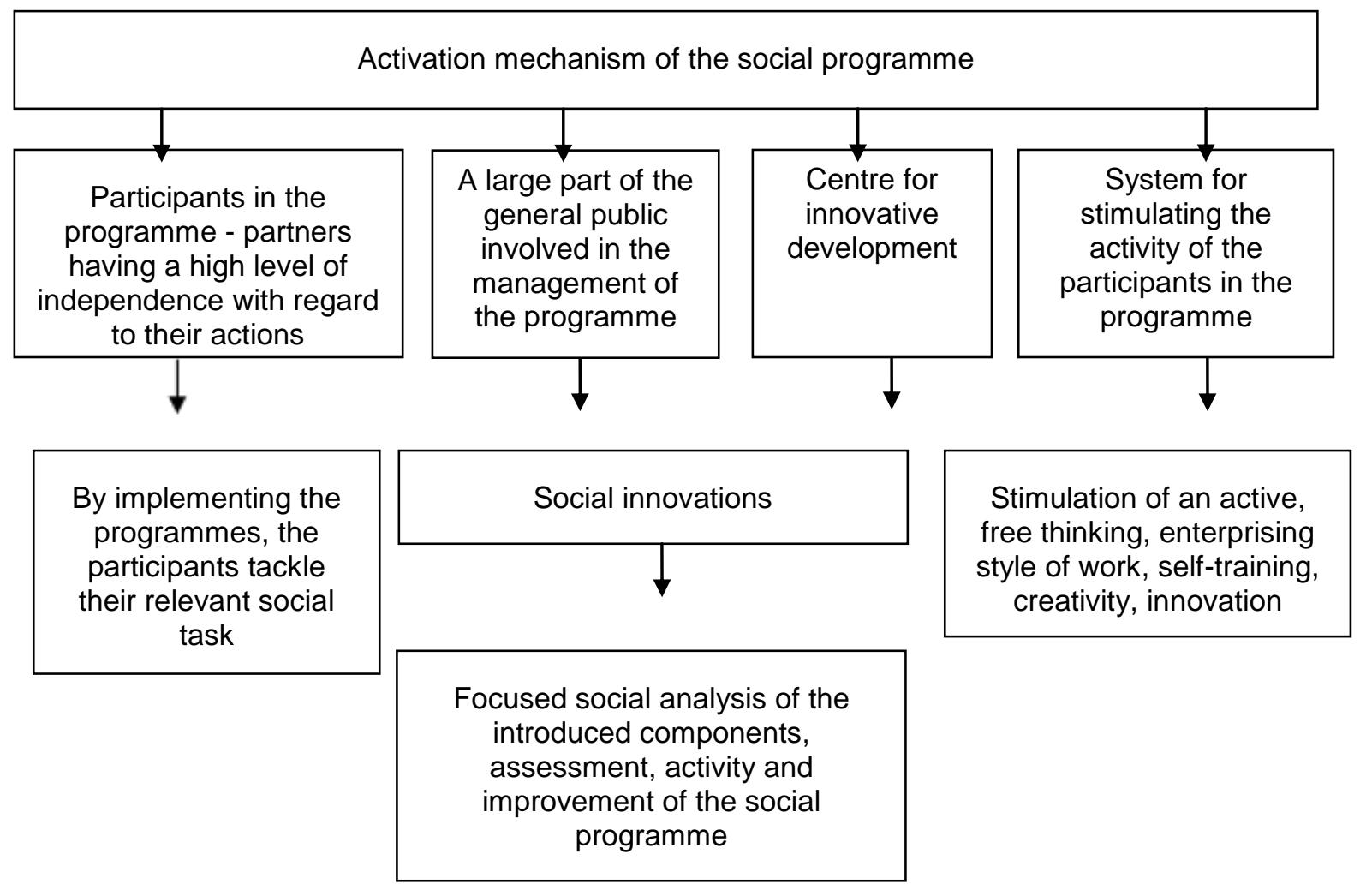

Fig. 3. Components of the mechanism for activating social programmes.

The active social programmes are thus directed to resolving social problems during the introduction of breakthrough, innovative social technologies, to attracting investments, to optimising the flows of social resources and to integrating the social systems. The development of the social programme renounces the principle of termination of the organised social events. Each active social project is first and foremost innovative as its main goal is to develop and use new ideas which could be new social technologies aimed at delivering social services and supporting the dynamic social development of the population. 
The active social programme is created as a set of social projectsunited by the idea of social interaction which ensures the coordination of the population's interests under the conditions of an unstable social environment. The active social programme is a systematic development. Each constituent part of the active social programme, taken separately, is interrelated and dependent on the other parts. As a rule, when the individual elements of the social programmes are implemented separately and isolated from the rest, this decreases the effectiveness of the implementation of the programme as a whole.

The unifying social idea of the active programme - this is the optimal synthesis of thoughts, ideas and goals of the participants in the programme, including members of the general public. The participants in the social programme are relatively independent and they act driven by their own interests - they pursue their own interest by their participation in the social programme. The development of the programme rests on a socially significant unifying idea so that the personal interests of the participants in the active social programme could be aligned with the goal of the programme itself. The social programme is developed by studying the ideas and innovative thoughts of the participants concerning the implementation of the active social project, analysing them thoroughly to form a unifying idea and devising schemes of the interests of the participants and the population. The structure of the active social programme is shaped using the data collected, then a network of organisations is established with the participants in the programme and the representative of the unifying social idea assumes the role of a coordintor and regulator of the programme implementation.

The active social programmes share a number of common features: they are designed to achieve specific goals; they include a coordinated implementation of interrelated activities; they have a limited validity with a specified beginning and a deadline for designing a new programme or its implementation; they are unique to a certain extent.

The result from the active social programming allows the complex programme to be implemented with maximum effectiveness under the conditions of a dynamically changing social environment. Besides, based on the unifying ideas the involvement of relatively independent social institutions is ensured through the coordination of their needs and interests. The active approach is primarily focused on the effective development of the social object of the programme by introducing break-through innovative technologies, engaging the general public in the management process, optimising the flows of resources and integrating the social systems of the participants in the programme. The term "active programming” highlights the continuous process of adaptation of the developed programme to the conditions of the social environment within the system. Therefore, the active social programme allows self-development of the system. The success of its management is determined significantly by the factors behind the interaction of the elements of the social programme with the constantly changing environment that has an impact on it. Unlike the classical social programmes, the active form of the programme is a creative self-developing project with a modifiable final social aim, means and tasks of the process of social changes, which repudiates the rigid static schemes of the classical social programming. The active social programmes are oriented to local social stabilisation under the unstable, dynamically changing conditions of the environment that has a social impact. The active project development is focused mainly on the effective development of the social objects during the introduction of innovations, on the optimisation of the flows of finances, resources and innovations, on the integration of the social and economic objects in the world economic connections.

The information gained during the social study of the conditions for the programme implementation is the basis for separating all significant system interrelated factors of social changes, reflecting the nature of the processes and phenomena that are taking place. The participants in the active social programme have and apply their skills for active creative behaviour related not only to the development of the social programme and the organisation of its implementation, but also to the ability to accumulate and reasonably appreciate various types of innovations. The implementation of the social programme depends to a great extent on professionalism. Under the present day conditions professionalism is a main criterion for the qualities of the programme. To this end, specialists from abroad need to be attracted reasonably

\section{DISCUSSION}

The criteria for the efficiency of the social activity are dependent on the goals and tasks related to the delivery of social services to the population and the degree of their achievement. In principle, the following shall be taken into account: the goals of the social activity can be studied on the level of society, regions, towns and villages, areas, groups of population and individuals (Terziev, Banabakova, Latyshev, Georgiev, 2017b, pp. 773-791; Terziev, Nichev, Stoyanov, Georgiev, 2017c, pp. 707-710; Terziev, Nichev, Stoyanov, Georgiev, Bogdanov, 2017d, pp. 701-706; Terziev, Nichev, Stoyanov, Georgiev, 2017e, pp. 695-700; Terziev, Nichev, Stoyanov, Georgiev, 2017f, pp. 690-694; Terziev, Latyshev, Georgiev, 2017g, pp.754-772; Terziev, Latyshev, Georgiev, 2017h, pp. 638-659; Terziev, Nichev, Stoyanov, Georgiev, 2017i, pp. 888-892; Terziev, Nichev, Stoyanov, Georgiev, 2017j, pp. 893-898; Terziev, Nichev, Stoyanov, Georgiev, Bogdanov, 
2017k, pp. 903-908; Terziev, Nichev, Stoyanov, Georgiev, 2017I, pp. 909-912; Terziev, Banabakova, Latyshev, Georgiev, 2017m, pp. 1056-1074).

First, the criteria for the efficiency of the social activity need to reflect the effectiveness of all types, forms and methods of social service of the population; second, they need to demonstrate the degree of effectiveness of the activity of the administration and the social institutions under the present day conditions in Bulgaria, where sweeping and complicated reforms are in place. Third, the criteria and indicators shall reflect the degree of efficiency of the leaders and of the management of the targeted and systematic social work with the population and the individuals who need professional social support.

Several approaches for ascertaining the effectiveness of the implemented social programmes can be employed.

The first is related to the objective assessment of the ratio of achieved results (output) and the associated costs. In this case a key problem is the measurement (description) of the results (output) and the costs. As far as the costs can be estimated and planned, so can the effectiveness of the social service be presumed, planned and actually achieve.

Another approach focuses on the assessment of the effectivenss of the social activity in terms of the degree of satisfaction of the social needs and expectations of the serviced customers (users and beneficieries of the project or programme). The subjective methods of assessment e.g. opinions, judgments, views (expressed about somebody or something more or less specifically) and the specific subject who performs the assessment of the effectiveness of the social activity are of great significance here. Therefore, in this case it is important to define and select the relevant source of information for the assessment (managers, specialists, representatives of surveillance bodies, users etc.); in other words, the subject is the bearer of information that is significant for the assessment. Moreover, it shall be taken into account that the assessment-related information derived from individuals is subjective. The more subjects are engaged in the assessment, the more this assessment will seek to gain (under other equivalent conditions) an objective and reliable picture of the activity of the social services and the implementation of the specific social programme/project on employment.

The complicated nature of the assessment requires a targeted organisation of the process of obtaining opinions, judgments and conclusions, expressed through specific forms and methods. In this case, this concerns the procedural and organisational aspect of the term „assessment of the effectiveness of the social service". If we want to assess someone or something, we need to organise the process of assessment (collecting and processing the assessment information), devising and employing specific assessment procedures (including for example complex methods of assessment verification).

The whole diversity of opinions given by various subjects go through certain procedures and stages during the process of assessment and turn into the resultant (final) assessments Generally, the organisational process of assessing the final information can be used to draw practical significant conclusions, to carry out relevant events and activities and to develop programmes for enhancing the effectiveness.

Before the start of the practical measurement of the effectiveness of the social activity, the researchers inevitably have to pose a number of questions: what is the object of the assessment, what is the subjectmatter of the assessment, who is the subject of the assessment, what criteria and indicators shall be used for the assessment, etc.

Effectivenss is an aggregate, integral indicator of the qualities of the system. It is determined by the external properties of the system (the meaning of the various indicators, characterising the capacity and the resources), as well as by the conditions where the specific system funcions. Therefore, it is more precise to talk about the operational effectiveness of the system when carrying out specific tasks under certain conditions, rather than about effectiveness in general. This allows all specific indicators of quality to be functionally connected in an integral indicator, i.e. effectiveness. This type of study of the quality helps to avoid many difficulties that occur during the analysis of complex systems.

Some of the factors that help define the goals and tasks of the assessment of the effectiveness of the social services are:

The analytical capabilities of the social employment service for identification and assessment of the queries;

The resources of the social employment service for operational response to the queries;

The capacity of the social employment service (including its level of interaction with government, state, commercial and public organisations); 
The social and economic conditions in the administrative area where the social employment service operates;

The qualification of the employees of the social employment service;

Special attention shall be paid to the assessment of the quality when assessing the effectiveness.

Indeed, many issues are resolved in the light of quality and the subjects of the management of the activity of the social employment service and the objects of its activity can function as indicators of quality (experts). The most typical operation during the assessment of quality is ranking. The objects (phenomena, processes) are considered ranked if a quantitative dimension of theirs corresponds to a particular quality they possess in varying degrees. The various social employment services use ranking in different situations. For example, ordering the objects (processes, phenomena) in terms of their position in space and time according to the degree of manifestation of a quality that cannot be measured by any objective scale, according to some measurable qualities or qualities susceptible to evaluation (as a rule the degree of manifestation of a quality used as a basis of ranking can always be practically measured), according to some quality which is generally measurable, yet at a particular moment cannot be measured due to practical or theoretical reasons.

The matrix "goal: means" can serve as a typical example when using expert assessments in the management. The cells of this matrix have to be filled in with data gained from the results of the expert assessments.

Depending on the subject-matter of the assessment there are various methodologies of assessing the effectiveness of the social protection system. We can call them provisionally „first tier methodologies” Each subject-matter of the assessment can be analysed in more detail and respectively, there will be „second tier methodologies". There is a specific methodology of assessing the effectiveness of each type of social service (social domestic, legal, rehabilitation, pscychological and consulting services, material support).

A comprehensive review and analysis of the efficiency of the government social services need to be carried out when analysing the national social policy.

In the organisation and administrative management theory the efficient management is defined as the relation between the net positive results (when the desired consequences exceed the non-desired) and the admissible costs. The decision is considered efficient if the best result has been achieved in accordance with the defined time costs and with the lowest selection costs.

\section{CONCLUSION}

The modern societies experience a crisis in the efficiency of the traditional systems of state government. There are three key factors that have been conducive to the crisis situation: sociopolitical, economic and sociocultural. To overcome the crisis of modern democracies and respectively to resolve the problem associated with the administrative state government, it is necessary to construct a government paradigm corresponding as far as possible to the new cultural, social and political situation. The synergy methodology can be used as a government paradigm. It is considered that the synergy theory which distances itself from the extreme deterministic and atomistic positions with regard to the analysis of the institutional systems, lends to scholars two key categories for the conceptualisation of the term „social efficiency”: „interpretative rationality" and "transaction costs". These two categories help achieve the main research objective: search for a general principle which allows the term "management decision” to be interpreted in the context of various institutional subsystems while recognising their own specific set of goals.

Apart from the "economic constituent" of the concept of efficiency /the ratio between the quantity of services delivered and the value or the quantity of resources needed for the delivery of the specified quantity of services /, it necessary to mention "the technical” or the organisational constituent defined by the goals to be pursued. Technical efficiency is a term that refers to the degree of adequacy of the civil services in relation to the needs, desires and resources of their customers.

The concept of social efficiency is studied in the context of the new post-classical paradigm of state government. With regard to the concept of social efficiency the western scholars (M.Dimock, Anicet le Pors, J.Lane, etc.) study the distribution of resources using methodologies that are closer to political economy and management of organisations. Social efficiency is defined as a function of the minimization of transaction costs (exchange-related costs). Therefore, a prerequisite for socially efficient general government is the existence of an effective mechanism for the coordination of social interactions. The transaction costs that are most typical of the state government system are as follows: costs related to opportunitstic behaviour (truancy, nepotism, agent's fees, blackmail, politisation costs, etc.).

It can be said that during a transition period there is a general system crisis that covers all spheres of society 
and lasts a long period of time. The success of the economic reforms is dependent on two groups of conditions: taking into account the subjects of the reforms (primarily the political elite of the country) and taking into account the need for objects of the reforms (the management teams and the personnel of enterprises with all forms of ownership, regional structures, the general public). The interests shall be taken into account on the „accounting” level and by studying more specific motivations covering the multi-layered structure of needs.

The experience of the industrial and postindustrial development of all countries in the world convincingly demonstrates the inadequacy of the purely technocratic approach to management. The new technologies, the information, taylorism and the economic and mathematical methods are very important, yet they allow true efficiency and competitiveness to be achieved only by taking into account the social motivation of the workers and by creating a well-planned system of incentives. Criteria for assessing the social efficiency of the state government are established. There two groups of such criteria: general system criteria which include equilibrium, stability, diversity, feedback, etc.; and specific social criteria the most important among which are social safety and social protection of the population.

Social efficiency is closely related to the safety of the social system. Statistically the safety of the social system can be construed as a spatial area or a state whose parameters are historically defined by a social ideal. For the contemporary Bulgarian society in particular going abroad, outside the boundary of the demarcated area implies that the society is approaching some form of a totalitarian regime.

\section{REFERENCE LIST}

Terziev, Venelin. (2017). Politiki i instrumenti za sotsialno razvitie, Innovations and Sustainability Academy, 2017, ISBN 978-619-7246-14-8, 318 str. (Terziev, Venelin. Политики и инструменти за социално развитие, Innovations and Sustainability Academy, 2017, ISBN 978-619-7246-14-8, 318 стр.).

Terziev, Venelin. (2018). Sotsialno razvitie- politiki i instrumenti, Nauchen institut za menaџment i znaeњe, Skopje, 2018, ISBN 978-608-4834-02-1, 307 р. (Терзиев, Венелин. Социално развитие- политики и инструменти, Научен институт за менаџмент и знаење, Скопје, 2018, ISBN 978-608-4834-02-1, 307 p.).

Terziev, Venelin. (2015). Assessment of active social policies impact of social policies on transformation processes in Bulgarian economy, Moscow, 2015, Publisher „Перо“, 110 p. (Publisher „Pero“).

Terziev, V., E. Arabska. (2015a). Theoretical and methodological basis of social programming and social activity, Kolektivnaya monografiya 2015, Ufa, Aeterna. Rossiya.ISBN 978-5-906808-20-2, 198 p. (Terziev, V., E. Arabska, Theoretical and methodological basis of social programming and social activity, Колективная монографрия 2015, Уфра, Аэтерна. Россия.ISBN 978-5-906808-20-2, 198 р.).

Terziev, V., Georgiev, M. (2018a). Sotsialna zashtita na uyazvimite grupi ot naselenieto v Balgariya. // Sbornik dokladi ot godishna universitetska nauchna konferentsiya 14-15 yuni 2018 g., Elektronno izdanie, NVU Vasil Levski- Veliko Tarnovo, Veliko Tarnovo, 2018, str. 970-975, ISBN 978-619-724620-9 (online e-book), ISSN 2367-7481 (Терзиев, В., Георгиев, М. Социална защита на уязвимите групи от населението в България. // Сборник доклади от годишна университетска научна конференция 14-15 юни 2018 г., Електронно издание, НВУ Васил Левски- Велико Търново, Велико Търново, 2018, стр. 970-975, ISBN 978-619-7246-20-9 (online e-book), ISSN 2367-7481).

Terziev, V., Georgiev, M. (2018b). Harakteristiki na sistemata za sotsialno podpomagane. // Sbornik dokladi ot godishna universitetska nauchna konferentsiya 14-15 yuni 2018 g., Elektronno izdanie, NVU Vasil Levski- Veliko Tarnovo, Veliko Tarnovo, 2018, str. 959-969, ISBN 978-619-7246-20-9 (online e-book), ISSN 2367-7481 (Терзиев, В., Георгиев, М. Характеристики на системата за социално подпомагане. // Сборник доклади от годишна университетска научна конференция 14-15 юни 2018 г., Електронно издание, НВУ Васил Левски- Велико Търново, Велико Търново, 2018, стр. 959-969, ISBN 978-619-7246-20-9 (online e-book), ISSN 2367-7481).

Terziev, V., Georgiev, M. (2018c). Sotsialna zashtita na uyazvimite grupi ot naselenieto v Balgariya. // Sbornik dokladi ot Godishna universitetska nauchna konferentsiya 14-15 yuni 2018g., Nauchno napravlenie „Sotsialni, stopanski i pravni nauki”, NVU Veliko Tarnovo, Veliko Tarnovo, Izdatelski kompleks na NVU „Vasil Levski”, 7, 2018, str. 188-193, ISBN 978-619-7246-20-9 (online e-book), ISSN 1314-1937 (Терзиев, В., Георгиев, М. Социална защита на уязвимите групи от населението 
в България. // Сборник доклади от Годишна университетска научна конференция 14-15 юни 2018г., Научно направление „Социални, стопански и правни науки”, НВУ Велико Търново, Велико Търново, Издателски комплекс на НВУ „Васил Левски”, 7, 2018, стр. 188-193, ISBN 978619-7246-20-9 (online e-book), ISSN 1314-1937).

Terziev, V., Georgiev, M. (2018d). Harakteristiki na sistemata za sotsialno podpomagane. // Sbornik dokladi ot Godishna universitetska nauchna konferentsiya 14-15 yuni 2018g., Nauchno napravlenie „Sotsialni, stopanski i pravni nauki”, NVU Veliko Tarnovo, Veliko Tarnovo, Izdatelski kompleks na NVU „Vasil Levski”, 7, 2018, str. 177-187, ISBN 978-619-7246-20-9 (online e-book), ISSN 1314-1937 (Терзиев, В., Георгиев, М. Характеристики на системата за социално подпомагане. // Сборник доклади от Годишна университетска научна конференция 14-15 юни 2018г., Научно направление "Социални, стопански и правни науки”, НВУ Велико Търново, Велико Търново, Издателски комплекс на НВУ „Васил Левски”, 7, 2018, стр. 177-187, ISBN 978-619-7246-20-9 (online e-book), ISSN 1314-1937).

Terziev, V., Banabakova, V., Georgiev, M. (2018e). Modern dimensions of social policies. // International journal scientific papers Vol 23.4 Promoted in Budva, Montenegro 24-27.05.2018, IKM - Skopje, 23, 2017, N 4, pp. 935-944, ISSN 1857-923X (for e-version) ISSN 2545- 4439 (for printed version).

Terziev, V., Banabakova, V., Georgiev, M. (2018f). Social support as part of social policy. // International journal scientific papers Vol 23.4 Promoted in Budva, Montenegro 24-27.05.2018, IKM - Skopje, 23, 2017, N 4, pp. 973-980, ISSN 1857-923X (for e-version) ISSN 2545 - 4439 (for printed version).

Terziev, V., Banabakova, V., Georgiev, M. (2018g). Structure of the social welfare system in Bulgaria. // International journal scientific papers Vol 23.4 Promoted in Budva, Montenegro 24-27.05.2018, IKM Skopje, 23, 2017, N 4, pp. 1275-1281, ISSN 1857-923X (for e-version) ISSN 2545 - 4439 (for printed version).

Terziev, V., Banabakova, V., Georgiev, M. (2018h). Role and place of social programing in public governance. // Mizhnarodnoï naukovo-praktichnoï konferentsiï «Zabezpechennya stalogo rozvitku ekonomiki: problemi, mozhlivosti, perspektivi» (16-17 lyutogo 2018 roku, m. Uzhgorod), Ministerstvo osviti i nauki Ukraïni Uzhgorodsykiy natsionalyniy universitet, 2018, s.93-98, ISBN 978-966-916-488-9 (Terziev, V., Banabakova, V., Georgiev, M. Role and place of social programing in public governance. // Міжнародної науково-практичної конференції «Забезпечення сталого розвитку економіки: проблеми, можливості, перспективи» (16-17 лютого 2018 року, м. Ужгород), Міністерство освіти і науки України Ужгородський національний університет, 2018, с.93-98, ISBN 978-966-916-488-9).

Terziev, V., Banabakova, V., Georgiev, M. (2018i). Social program as a product of social programming. // Mizhnarodnoï naukovo-praktichnoï konferentsiï «Zabezpechennya stalogo rozvitku ekonomiki: problemi, mozhlivosti, perspektivi» (16-17 lyutogo 2018 roku, m. Uzhgorod), Ministerstvo osviti i nauki Ukraïni Uzhgorodsykiy natsionalyniy universitet, 2018, s. 99-104, ISBN 978-966-916-488-9 (Terziev, V., Banabakova, V., Georgiev, M. Social program as a product of social programming. // Міжнародної науково-практичної конференції «Забезпечення сталого розвитку економіки: проблеми, можливості, перспективи» (16-17 лютого 2018 року, м. Ужгород), Міністерство освіти і науки України Ужгородський національний університет, 2018, с. 99-104, ISBN 978-966-916-488-9).

Terziev, V., Banabakova, V., Georgiev, M. (2018j). Social efficiency as a measure of social activities. // Mizhnarodnoï naukovo-praktichnoï konferentsiï «Zabezpechennya stalogo rozvitku ekonomiki: problemi, mozhlivosti, perspektivi» (16-17 lyutogo 2018 roku, m. Uzhgorod), Ministerstvo osviti i nauki Ukraïni Uzhgorodsykiy natsionalyniy universitet, 2018, s. 104-109, ISBN 978-966-916-488-9 (Terziev, V., Banabakova, V., Georgiev, M. Social efficiency as a measure of social activities. // Міжнародної науково-практичної конференції «Забезпечення сталого розвитку економіки: проблеми, можливості, перспективи» (16-17 лютого 2018 року, м. Ужгород), Міністерство освіти і науки України Ужгородський національний університет, 2018, с. 104-109, ISBN 978-966-916-488-9).

Terziev, V., Banabakova, V., Georgiev, M. (2018k). Assessment of the effectiveness of social programing. // Mizhnarodnoï naukovo-praktichnoï konferentsiï «Zabezpechennya stalogo rozvitku ekonomiki: problemi, mozhlivosti, perspektivi» (16-17 lyutogo 2018 roku, m. Uzhgorod), Ministerstvo osviti i nauki Ukraïni Uzhgorodsykiy natsionalyniy universitet, 2018, s. 110-115, ISBN 978-966-916-488-9 (Terziev, V., Banabakova, V., Georgiev, M. Assessment of the effectiveness of social programing. // Міжнародної науково-практичної конфреренції «Забезпечення сталого розвитку економіки: проблеми, можливості, перспективи» (16-17 лютого 2018 року, м. Ужгород), Міністерство освіти і науки України Ужгородський національний університет, 2018, с. 110-115, ISBN 978-966-916-4889). 
IJASOS- International E-Journal of Advances in Social Sciences, Vol. IV, Issue 12, December 2018

Terziev, V., Banabakova, V., Georgiev, M. (2018I). Social activity of human resource as a basis of effective social policy. // Mizhnarodnoï naukovo-praktichnoï konferentsiï «Zabezpechennya stalogo rozvitku ekonomiki: problemi, mozhlivosti, perspektivi» (16-17 lyutogo 2018 roku, m. Uzhgorod), Ministerstvo osviti i nauki Ukraïni Uzhgorodsykiy natsionalyniy universitet, 2018, s. 116-121, ISBN 978-966-916488-9 (Terziev, V., Banabakova, V., Georgiev, M. Social activity of human resource as a basis of effective social policy. // Міжнародної науково-практичної конфреренції «Забезпечення сталого розвитку економіки: проблеми, можливості, перспективи» (16-17 лютого 2018 року, м. Ужгород), Міністерство освіти і науки України Ужгородський національний університет, 2018, с. 116-121, ISBN 978-966-916-488-9).

Terziev, V., Banabakova, V., Georgiev, M. (2018m). Strategic advantages of an active social program. // Mizhnarodnoï naukovo-praktichnoï konferentsiï «Zabezpechennya stalogo rozvitku ekonomiki: problemi, mozhlivosti, perspektivi» (16-17 lyutogo 2018 roku, m. Uzhgorod), Ministerstvo osviti i nauki Ukraïni Uzhgorodsykiy natsionalyniy universitet, 2018, s. 122-127, ISBN 978-966-916-488-9 (Terziev, V., Banabakova, V., Georgiev, M. Strategic advantages of an active social program. // Міжнародної науково-практичної конфреренції «Забезпечення сталого розвитку економіки: проблеми, можливості, перспективи» (16-17 лютого 2018 року, м. Ужгород), Міністерство освіти і науки України Ужгородський національний університет, 2018, с. 122-127, ISBN 978-966-916-488-9).

Terziev, V., Banabakova, V., Georgiev, M. (2018n). Assessment of the effectiveness of social programming. // Mizhnarodnoï naukovo-praktichnoï konferentsiï «Zabezpechennya stalogo rozvitku ekonomiki: problemi, mozhlivosti, perspektivi» (16-17 lyutogo 2018 roku, m. Uzhgorod), Ministerstvo osviti i nauki Ukraïni Uzhgorodsykiy natsionalyniy universitet, 2018, s. 127-131, ISBN 978-966-916-488-9 (Terziev, V., Banabakova, V., Georgiev, M. Assessment of the effectiveness of social programming. // Міжнародної науково-практичної конференції «Забезпечення сталого розвитку економіки: проблеми, можливості, перспективи» (16-17 лютого 2018 року, м. Ужгород), Міністерство освіти і науки України Ужгородський національний університет, 2018, с. 127-131, ISBN 978-966-916-4889).

Terziev, V., Banabakova, V., Georgiev, M. (20180). The social program as a part of development strategies. // Mizhnarodnoï naukovo-praktichnoï konferentsiï «Zabezpechennya stalogo rozvitku ekonomiki: problemi, mozhlivosti, perspektivi» (16-17 lyutogo 2018 roku, m. Uzhgorod), Ministerstvo osviti i nauki Ukraïni Uzhgorodsykiy natsionalyniy universitet, 2018, s. 132-137, ISBN 978-966-916-488-9 (Terziev, V., Banabakova, V., Georgiev, M. The social program as a part of development strategies. // Міжнародної науково-практичної конфреренції «Забезпечення сталого розвитку економіки: проблеми, можливості, перспективи» (16-17 лютого 2018 року, м. Ужгород), Міністерство освіти і науки України Ужгородський національний університет, 2018, с. 132-137, ISBN 978-966-916-4889).

Terziev, V., Banabakova, V., Georgiev, M. (2018p). Social programming as a possibility to increase social efficiency. // Mizhnarodnoï naukovo-praktichnoï konferentsiï «Zabezpechennya stalogo rozvitku ekonomiki: problemi, mozhlivosti, perspektivi» (16-17 lyutogo 2018 roku, m. Uzhgorod), Ministerstvo osviti i nauki Ukraïni Uzhgorodsykiy natsionalyniy universitet, 2018, s. 137-142, ISBN 978-966-916488-9 (Terziev, V., Banabakova, V., Georgiev, M. Social programming as a possibility to increase social efficiency. // Міжнародної науково-практичної конференції «Забезпечення сталого розвитку економіки: проблеми, можливості, перспективи» (16-17 лютого 2018 року, м. Ужгород), Міністерство освіти і науки України Ужгородський національний університет, 2018, с. 137-142, ISBN 978-966-916-488-9).

Terziev, Venelin. (2017a). Modeling active social programs in Bulgaria through social entrepreneurship encouragement. // 3rd Central \& Eastern European LUMEN International Conference, New Approaches in Social and Humanistic Sciences NASHS 2017, Chisinau, Republic of Moldova, June 810, 2017, 2018, pp.505-516, ISSN (print): 2601 - 2510, ISSN (on-line): 2601 - 2529, ISSN-L: 2601 2510, ISBN: 978-1-910129-15-9.

Terziev, V., Banabakova, V., Latyshev, O., Georgiev, M. (2017b). Opportunities of application of the balanced scorecard in management and control. // 3rd International Conference on Advances in Education and Social Sciences. International Organization Center of Academic Research, www.ocerint.org, 2017, pp. 773-791, ISBN: 978-605-82433-0-9.

Terziev, V., Nichev, N., Stoyanov, E., Georgiev, M. (2017c). Key aspects of the problems of administrative control in Bulgaria. // Proceedings of ADVED 2017- $3^{\text {rd }}$ International Conference on Advances in Education and Social Sciences 9-11 October 2017- Istanbul, Turkey. International Organization 
IJASOS- International E-Journal of Advances in Social Sciences, Vol. IV, Issue 12, December 2018

Center of Academic Research, www.ocerint.org, 2017, pp. 707-710, ISBN: 978-605-82433-0-9.

Terziev, V., Nichev, N., Stoyanov, E., Georgiev, M., Bogdanov, P. (2017d). Opportunities for strategic development of small business in Bulgaria. // Proceedings of ADVED 2017- 3rd International Conference on Advances in Education and Social Sciences 9-11 October 2017- Istanbul, Turkey. International Organization Center of Academic Research, www.ocerint.org, 2017, pp. 701-706, ISBN: 978-605-82433-0-9.

Terziev, V., Nichev, N., Stoyanov, E., Georgiev, M. (2017e). On some of the blank points in the application of administrative control in Bulgaria. // Proceedings of ADVED 2017- $3^{\text {rd }}$ International Conference on Advances in Education and Social Sciences 9-11 October 2017- Istanbul, Turkey. International Organization Center of Academic Research, www.ocerint.org, 2017, pp. 695-700, ISBN: 978-60582433-0-9.

Terziev, V., Nichev, N., Stoyanov, E., Georgiev, M. (2017f). A general principle of the development process of Balanced scorecards as an instrument of control. // Proceedings of ADVED 2017- ${ }^{\text {rd }}$ International Conference on Advances in Education and Social Sciences 9-11 October 2017- Istanbul, Turkey. International Organization Center of Academic Research, www.ocerint.org, 2017, pp. 690-694, ISBN: 978-605-82433-0-9.

Terziev, V., Latyshev, O., Georgiev, M. (2017g). Building competencies for social work through continuing vocational training. // Proceedings of ADVED 2017- $3^{\text {rd }}$ International Conference on Advances in Education and Social Sciences 9-11 October 2017- Istanbul, Turkey. International Organization Center of Academic Research, www.ocerint.org, 2017, pp.754-772, ISBN: 978-605-82433-0-9.

Terziev, V., Latyshev, O., Georgiev, M. (2017h). Building competencies for social work through continuing vocational training. // IJAEDU- International E-Journal of Advances in Education, International Organization Center of Academic Research, www.ocerint.org, 3, 2017, N 9, pp. 638-659, e-ISSN: 2411-18.

Terziev, V., Nichev, N., Stoyanov, E., Georgiev, M. (2017i). A general principle of the development process of Balanced scorecards as an instrument of control. // IJAEDU- International E-Journal of Advances in Education, International Organization Center of Academic Research, www.ocerint.org, 3, 2017, N 9, pp. 888-892, e-ISSN: 2411-18.

Terziev, V., Nichev, N., Stoyanov, E., Georgiev, M. (2017j). On some of the blank points in the application of administrative control in Bulgaria. // IJAEDU- International E-Journal of Advances in Education, International Organization Center of Academic Research, www.ocerint.org, 3, 2017, N 9, pp. 893-898, e-ISSN: 2411-18

Terziev, V., Nichev, N., Stoyanov, E., Georgiev, M., Bogdanov, P. (2017k). Opportunities for strategic development of small business in Bulgaria. // IJAEDU- International E-Journal of Advances in Education, International Organization Center of Academic Research, www.ocerint.org, 3, 2017, N 9 , pp. 903-908, e-ISSN: 2411-18.

Terziev, V., Nichev, N., Stoyanov, E., Georgiev, M. (2017I). Key aspects of the problems of administrative control in Bulgaria. // IJAEDU- International E-Journal of Advances in Education, International Organization Center of Academic Research, www.ocerint.org, 3, 2017, N 9, pp. 909-912, e-ISSN: 2411-18.

Terziev, V., Banabakova, V., Latyshev, O., Georgiev, M. (2017m). Opportunities of application of the Balanced scorecard in management and control. // IJAEDU- International E-Journal of Advances in Education, International Organization Center of Academic Research, www.ocerint.org, 3, 2017, N 9, pp. 1056-1074, e-ISSN: 2411-18Social Sciences 9-11 October 2017- Istanbul, Turkey, 2017, ISBN: 978-605-82433-0-9, pp.671-677. 